\title{
RESEARCH
}

Open Access

\section{Pedagogic dilemmas to flows of knowledge in the age of digital technology}

Ángel San Martín Alonso ${ }^{{ }^{*}}$ and Ángel García del Dujo ${ }^{2}$

\footnotetext{
* Correspondence: asanmart@uv.es 'Departamento de Didáctica y Organización Escolar, Avda. Blasco Ibáñez 30, 46010 Valencia, Spain Full list of author information is available at the end of the article
}

\begin{abstract}
The main purpose of this paper is to argue why we adopted the socio-technical system as a heuristic device. We understand it is a good methodological resource to interpret what is happening in education systems with the progressive introduction of digital technologies, helping us to understand the changes that are occurring, and documented here, concomitant with the technological innovation, also involved political factors and economic modeling ending the "new education".
\end{abstract}

Keywords: Pedagogy, Socio-technical system, School management, Internet

\section{Introduction: the internet and the pedagogy without rules}

There are two narrative resources which have become recurring arguments of irrefutable authority in many reflections on education. One of them is the allusion to the controversial PISA reports and the other one is the reference to the transforming impact of information technology. Moreover, they are usually linked to each other so that their authority is strengthened. However, even though they are usually resorted to, the deeper meaning of the complex relationship between technology and education is not evident. Nevertheless, the two of them are common topics due to the fact that both offer surprising results and, above all, because both initiatives have become a strategic factor for the neoliberalism in contemporary societies (Allen \& Light, 2015; OECD, 2015a).

One of the consequences of the aforementioned relationship is the fact that the educational institution is progressively losing its monopoly and responsibilities to educate and teach young generations. This loss is strengthened by the intensive transfer of technology with innovative purposes every time teaching practices are patterned by a technical system, especially during the last two decades (García \& San Martín, 2014). For this article, this system is adopted as a methodological resource in order to explain and reflect on what is happening in education. In any case, if previously the school followed Fordism, it now has to follow what is called "fabricación digital" (Fundación Telefónica, 2014, see "Bits and Atoms"). It will be necessary to be prepared so that teaching is not reduced to a simple instruction or what would be worse, to training.

This article will not focus on to what extent information technology is involved as an "object" or "medium" for teaching. These aspects are already common in literature. The focus will be, however, on analysing the room left for pedagogy by technologies when teaching itself becomes a part of the design and development of an important

(c) 2016 The Author(s). Open Access This article is distributed under the terms of the Creative Commons Attribution 4.0 International License (http://creativecommons.org/licenses/by/4.0/), which permits unrestricted use, distribution, and reproduction in any medium provided you give appropriate credit to the original author(s) and the source, provide a link to the Creative Commons license, and indicate if changes were made. 
area of technology (Hwang \& Tsai, 2011). According to Piscitelli (2015): "transforming the teaching and learning processes into algorithms". This phenomenon encourages reductionism. Some aspects should be discussed such as: how relevant pedagogical models inherited from modernity are, to what extent using virtual platforms improve in teaching improves students' learning, and especially, if their access contributes to equality among all social groups. Similarly, we should reconsider the epistemological and methodological assurance of the production of knowledge as well as some of the many other aspects regarding the identity of the human being as an individual and citizen. This is an ongoing and essential task of any teaching-learning process. Moreover, this task may be subject to restructuring because of these technologies. Either way, we will see that these are aspects which are interspersed with different components of the technical system.

\section{The digitalisation of teaching}

In relation to the presentation of a monograph on "digital culture", the economist Bustamante (2011, p. 3) notes that in this expression the adjective "digital" contributes to confuse "el contenido con el continente". The author informs us that contents are completely different from "la tecnología de almacenamiento y transmisión". Despite the difference of both processes -culture and technology-, this author claims that nowadays cultural creation must be understood under "la relación dialéctica entre innovación tecnológica y transformación social, que abarca desde los nuevos modos de creación simbólica hasta sus procesos de almacenamiento, difusión y uso social". For this approach, "digitalisation" must be understood not as technology -even though it is technology- but as a part of an individual and collective expertise with innovative devices that constitute a social-technical system.

Therefore, nowadays digitalisation as a technological process is such an important phenomenon that can influence everything e.g. words, images, sounds, formulas, etc. Everything is convertible into zeroes and ones; that is, algorithms. Thus, in the current phase of capitalism, digitalisation is an abstract technique that allows all kind of signals to be treated as "una cadena de signos binarios, codificados por la lógica booleana". This way, signals can pass with the same code and be transportable in the same channel (Míguez, 2008, p. 8). And he adds: "La digitalización permitió al capital reestructurar por completo el trabajo informacional y recalificar muchas actividades como las vinculadas al mundo financiero, las comunicaciones, (...), la enseñanza y la investigación".

From this perspective, we resort to Quintilla's social-technical approach (1998: 52). According to his approach, innovation and technological development include "no sólo elementos cognitivos o económicos, sino también elementos sociales, organizativos, culturales, etc." In other words, these systems are educational environments and even more properly said, "Learning environments". The so-called "network capitalism" virtualises organisations and most of their key components. It is a process by which "se van sustituyendo formas, modos y costumbres de relación social y cultural directa por formas mediadas absolutamente por las nuevas mercancías digitalizadas y por sus iconos" (Alonso, 2007, p. 21). Virtualisation promoted by Post-Fordism encourages a virtual culture based on individualisation and especially on disintermediation. The intensity and speed of flows impose the logic of the technological "invisible hand" which neutralises "controls, social references or institutional democracies". 
Many processes have been digitalised in teaching as well as in other fields such as cultural, manufacturing or service. These processes are primarily aimed at managing and offering self-sustaining educational programmes for different levels and training areas. This would be the area in which the most "innovative" pedagogy is developed: the area for the digitalisation of teaching. It is an area that for now is based on a didactic narrative instrumentally oriented. Its approach is characteristic of systems engineering, software development, graphic design, etc. The experienced progress is based on the convergence of different processes: information becomes a myth, costs and responsibilities become external. The education institutional framework becomes deteriorated while management politics is imposed on teaching and learning.

\section{Pedagogic dilemmas provoked by digitalised environments}

It is inevitable that the educational institution and the maintenance of democracy are linked. Having said that, it does not seem that the dream of "digital democracy" will solve the problem caused by the loss of intermediation. However, according to all indicators, it seems that there will be more difficulties. Due to the fact that informational networking does not give a satisfactory answer, Innerarity (2013, p. 96) demands mediation instances and procedures which must accept the requirement of "profesionalidad y representación". The quoted philosopher concludes by saying that without them "el mundo es menos inteligible y más ingobernable". Therefore, we should wonder whether the process by which teaching and learning becomes algorithms will remain committed to democratic citizenship -even if it will promote regeneration and reconstruction of the concept and phenomenon of citizenship- (García, 2015), or if, on the contrary, this technology in a socio-technical context will end up contributing to its deterioration and deformation. These questions are not external to the mentioned changed which need pedagogy to reconsider.

\section{The relationship between means and users}

The socio-technical system does not work on its own but with different resources and materials such as technological devices, physical spaces or connectivity as well as knowledge or the ability to understand the symbols on the screen. Some of them must be highlighted: the constant changing of both, its design and its operating potential, and the user's requirements through the interface.

According to some research carried out by the OECD, "el $93 \%$ de los alumnos de 15 años de edad de la OCDE asisten a una escuela en la que cuentan con acceso a un ordenador y prácticamente el mismo porcentaje (92,6 \%) dispone igualmente de acceso a Internet" (Pedró, 2011, p. 17). However, according to this research, the computers students have at home are better than the ones offered at schools. The difference is almost 18 percentage points on average among all countries (in Spain this percentage is a bit smaller).

We also find out that $65 \%$ of teachers accept that they use a computer or printer "casi todos los días" (Barquín et al., 2011, p. 36). However, although 86 \% recognise these tools are useful for students in teaching, only $34 \%$ use them for teaching. The aforementioned third of skeptical teachers are young people who are able to use these devices properly. Pedró (2011, p. 22) draws a much more pessimist conclusion from some data given by OECD by saying "La tecnología no se usa en todas las materias con 
igual intensidad y, por consiguiente, hay un porcentaje elevado de materias en las cuales el nivel de integración es prácticamente inexistente...”. The content of the subject is not as determinant of these differences as teaching methodologies that help improve performance (OECD, 2015b).

One of the components of the system which is most used at the moment is the one related to the curriculum content. According to ANELE, in 2011, more than 868 million euros were invoiced for school textbooks. Of this total, 9.4 million euros came from digital books. During the previous year, the offered titles were multiplied by 10 , but the income was increased only by $29 \%$. This represents only $1.07 \%$ of the total income by teaching books. Therefore, this association comes to the conclusion that the income is still modest in relation to the editing and innovation effort made by publishers in recent years. Finally, it is necessary to remember that there are more than 15,000 jobs directly linked to publishing. A $40 \%$ of these are within the textbook subsector. Moreover, it cannot be forgotten that the number of books exported increases every year. It exceeded 400 million euros in 2011 (ANELE, 2012, p. 6).

\section{Changing roles and the incorporation of new agents}

The growing hegemony of the socio-technical system has some consequences in teaching. According to Antunes (2012), one these consequences is the incorporation of "morfología del trabajo".

Due to capitalism, the information production and distribution is now considered a job for both the person who creates a product and the one who buys it (Míguez, 2008, p. 16). In this case, both teachers and students would perform a complex job which will not be as physical or routine as the job from the chain. The job is now done before the interface on a screen that requires a person to interpret different symbols. Thus, this job could be described as cognitive.

It is true that very few people question the relevance of teaching. However the tasks of teaching and professional recognition are unclear. A new context is created in which teachers lose credibility and authority because of the proliferation of resources in the classroom and students' experience with means. One part of its role is played by attractive technological applications which are activated by the user. This requires teaching training to be redesigned. (Hepp et al., 2015, p. 36). Without a doubt, in this context there are some functions which help empower teachers. These must be fostered to the extent they promote the comprehensive human development.

It is believed that it is extremely difficult to anticipate how teachers' role will be in a few years' time. However, Tenti Fanfani (2010) foresees that this job will be carried out by different professionals who will share this responsibility with teachers. New teachers will have to accept responsibility for tasks such a designing virtual programmes on training; creating content; activating and managing virtual networks, interacting with people in different contexts or evaluating with very sophisticated technological tools. For a different person who observes this changing progress, teachers are not "un mero transmisor de conocimientos para desempeñar el rol de facilitador, o mediador de procesos de aprendizaje..." (Díaz Becerro, 2009, p. 3).

Not only is the teacher's role changing but also the student's. Students are gaining prominence in the emerging systems. In fact, “...es el propio alumno el que va construyendo su conocimiento a través de las interacciones con otros estudiantes como él, 
con el profesor y con el material didáctico disponible", especially on the virtual platform. (Díaz Becerro, 2009, p. 4). In a certain way, an individual with fundamental rights starts to self-manage the learning opportunities that enable him to be an entrepreneur. On the way, some criteria traditionally unquestioned in the process of knowledge such as truth and objectivity are reconfigured. These give way to more functional criteria such as utility criteria. (Lankshear, Peters, \& Knobel, 2000).

These changes in functions, criteria and tasks are not alone. They are together with new agents in schools. Some of them are already held by entities such as Google, Microsoft, Telefónica, Wikipedia, Facebook, Twitter, financial institutions, publishing groups, NGOs, companies that offer administrative and management services, agencies which provide quality certificates and some other industries of knowledge and culture. Not only do they offer curriculum materials and technological resources but also they offer training.

\section{Structure based on management and control of processes}

The socio-technical system is not only based on a complex network of internal relations, but also with the environment (Durbin, 2007; Quintanilla, 1998). So, technologies are incorporated in conventional organisations. These technologies operate mainly with logic networks either because with them new virtual communities are created or because by using them, the actual school community becomes part of a job network. In both cases, and as Castells (2009, p. 47), the networks operate according to a binary protocol "de inclusion-exclusión" which generates complex communication structures established around "un conjunto de objetivos que garantizan al mismo tiempo, unidad de propósitos y flexibilidad en su ejecución gracias a su capacidad para adaptarse al entorno operativo".

In educational institutions the hierarchical and vertical logic lives together with the one based on networks. This situation develops towards a management model focused on the technocratic dimension. It is expected that the different nodes fulfil their mission effectively. The decentralised organisation of work requires nucleus strategically positioned to control the process, for example PISA assessments. This teaching model does not escape a more general management, that is: "El movimiento centrífugo de la producción se equilibra mediante la tendencia centrípeta del mando" (Hardt \& Negri, 2002, p. 276).

In this system the instance with authority and control capacity no longer depends on the leadership of an individual. It is now associated with the combination of technical and specialised skills of the network. In this way, the word "technician" appears (advisor, expert, IT coordinator, and autodidact). This person is in charge of the technological equipment but he/she is also a specialist in learning difficulties, an advisor for training, and an evaluator who applies diagnostic tests. What is more striking is the fact that the number of routine tasks (accounting, administrative, certifications, disciplinary and academic tasks) which are made exclusively by technological applications is increasing.

\section{Goals and purposes}

It is obvious that virtual learning environments do not longer respond to the classic criteria of Fordism. They do respond to the criteria of horizontal restructuring. Technology is imposing a new way of organising work and social networks around pedagogical knowledge. Paraphrasing Coriat (1991, p. 35), it would be important to mention that if computers appropriate the skills associated with teaching, then the 
activity of teaching can be done on a large scale and without any specialised knowledge. Although this is technically possible, it is not possible from a pedagogical perspective because citizenship and coexistence must be learnt at school.

The concurrence of a series of technological innovations, accompanied by political and economic conditions, encourages the setting of a new model of teaching and learning. On the one hand we are moving towards an offer "desescolarizada" because, as Tenti Fanfani (2010, p. 44) points out, schools do not have the monopoly on formal learning anymore. The "desarrollo acelerado de las tecnologías de la información y la comunicación" allows these technologies to be used in order to provide "nuevas formas de ejercicio de la enseñanza". The purpose of this digital model is to propose to the public a different relationship with knowledge production and access either through the interface or curriculum development.

Pedagogical digitalisation is the result of old teaching strategies translated into algorithms. This process is exactly what happens in production and service sectors in order to strengthen productivity based on individual management and innovation, which is a propitious area for the "new public management". Responding to this dynamic has become a technical problem nowadays. However, rebuilding teaching conditions -within or outside the school, with or without technologies- is politics. This does not arises interest in education anymore.

Unquestionably, computers and telecommunications provide access to information, data, documents and other materials, but knowledge is something else. Bunge (2002, p. 25), says specifically that "Sólo un cerebro viviente y bien pertrechado puede inventar ideas radicalmente nuevas, en particular problemas, analogías, principios de elevado nivel y algoritmos". Moreover and unlike computers, the aforementioned philosopher adds that that brain is "capaz de emitir juicios morales autónomos".

\section{Discrepancies about results}

The socio-technical system has provided teaching with platforms and virtual environments which organise teaching and learning processes. These platforms and virtual environments have been well accepted. Students can manage their own learning process through a succession of windows. Despite their variety and technological approach all of them can be encompassed under the label Learning Management Systems (LMS). Although they are usually activated and managed from traditional institutions, they are presented as an alternative to classrooms and school laboratories. The new virtual platform lets teachers and pupils perform their tasks through technological mediation of communicative exchanges (Luckin, 2010). Digital technology can copy on the board a classroom, a workshop, a laboratory or the place where the computer is as well as interconnect horizontally all registered users on the platform.

As some surveys have confirmed, schools have access to multiple platforms: one of them for administration and another one for academic activities which are offered by the Administration or by the market such as Moodle. Moreover there are some repositories and virtual resources offered by public and private entities. This combination poses some difficulties if we add institutional programmes and innovative initiatives in which schools participate.

On the one hand, this dynamic involves actors in school tasks. They do not always have the legitimacy and relevance to act in the area of institution. Some reasonable doubts arise about how to regulate the use of mobile phones in schools if "the informed 
consent" is enough so that a private company has files with students' academic and disciplinary data or with records from video cameras installed in the entrance to highschools. On the other hand, recent results are not entirely satisfactory if we refer to the results of school learning. In a meta-analysis from PISA-2012 report, it is concluded that students who make a heavy use of computer and the Internet do not perform better in reading or problem solving (Avvisati, 2015).

\section{Pedagogical challenges on the internet}

We are experiencing the typical uncertainties of changing times, especially the uncertainties of such important changes as moving from analog to digital. Moving from Fordism to a system operated by virtual platforms. However, according to Allen and Light (2015, p. 17) these changes are possible. Therefore, they do not depend on the evolution of technology. This is, doubtless, a stimulus to rethink issues such as the ones stated below.

a) It is necessary to analyse rigorously the micro-politics of schools. They are doomed to resolve the contradictions of production and copy created by devices in daily tasks. Both should be sieved with pedagogical filters in order to create a new and socially valuable knowledge (De Oliveira et al., 2015).

b) The equipment and access are imposed from the so-called new spirit of capitalism. The only alternative is defend the prevalence of school as a social intermediary and as a guarantor. Its goal is to keep this way of schooling since it is more supportive and fair than the digital one. Moreover, in this way of schooling, coexistence is learnt. Anyway, in this new situation, teachers have more responsibilities than in the past (Cochran-Smith et al., 2006). That is the reason why contents and methodologies in teaching training should be revised.

c) On the other hand, these platforms can be used outside schools. Therefore, learners have more responsibilities of their own learning. Moreover their objectives are incisively monitored (Kovács, 2002, p. 46). But in these circumstances, one should ask about the subjectivity and sociability promoted among users of virtual environments, about the identity of users as individuals and citizens.

d) School contents and practices have been regulated by BOE (Official State Gazette) and also by textbooks, but now the number of sources is virtually unlimited. The fact that there are more sources means that there are new and important problems. These are pedagogical, technological, and management problems. They are considered pedagogical because working with textbooks is different from working with digitalised content on interactive boards. Technological problems regarding format and means. Finally, there are problems in relation to what is taught in the education system, lesson plans available in repositories, learning objects, libroweb or eBooks. In spite of these problems and without hiding epistemological problems regarding knowledge and great variety of sources, it is a positive value that teachers must manage.

e) Screens are designed with words, icons and sounds whose meaning is a particular instruction. The user can choose to active them in order to turn the machine on. This way, an education model appears which can be described as ubiquitous, independent and technologically scheduled. Its requirements are no longer associated with the logic of spoken and written language in analog format or 
with face-to-face teaching. It is a model that should take into account the performance of the invested resources needed to turn it on.

f) As nobody questions the potential of this technology to "operate" with some information, it is important to be aware that it is more than an information and communication tool. It is also a way of thinking and acting individually and socially. And thus they generate culture and identities which need current criteria (Ibáñez-Martín, 2015).

\section{Authors' information}

San Martín is a full professor of Didactic and School Organisation at University of València. His teaching and researching field are school organisation and educational technology. His activity is mainly focused on studying the cultural, political and organisational synergies between technological evolutions and teaching practices in schools. The main topics are literacy, digital citizenship, technology transfer and innovation practices, and curriculum materials. Some of his recent publications are La escuela enredada (Gedisa), and his compilation Tecnologías educativas 2.0 (Pearson). Moreover, he coordinates the research group called Curriculum, Resources and Educational Institutions (CRIE).

García del Dujo is a graduate and PhD in Philosophy and Learning Sciences. He is a full professor in the Department of Theory and History of Education at University of Salamanca. He is the author and co-author of several books and articles for magazines specialised in theory and history of education and social pedagogy. His research areas are the analysis of educational processes; training processes in virtual spaces; values and limits of education; and new and old epistemologies in education. García del Dujo is also the Director of the Research Group: Processes, Spaces and Educational Practices. Furthermore, he also serves on the editorial boards of several scientific magazines and he is the Director of Teoría de la Educación. Revista Interuniversitaria.

\section{Author details}

${ }^{1}$ Departamento de Didáctica y Organización Escolar, Avda. Blasco Ibáñez 30, 46010 Valencia, Spain. ²Departamento de Teoría e Historia de la Educación, Paseo de Canalejas, 169, 37008 Salamanca, Spain.

Received: 25 November 2015 Accepted: 18 May 2016

Published online: 01 July 2016

References

Allen, D., \& Light, J. S. (Eds.). (2015). From Voice to Influence. Understandig Citizenship in a Digital Age. Chicago: The University of Chicago Press.

Alonso, L. E. (2007). Las nuevas culturas del consumo y la sociedad fragmentada. Pensar la publicidad, 1(2), 13-32.

ANELE. (2012). La edición de libros de texto en España. Madrid: ANELE. Retrieved from: http://www.anele.org/pdf/ edicion_libros_texto.pdf.

Antunes, R. (2012). La nueva morfología del trabajo y sus principales tendencias: informalidad, infoproletariado, (in)materialidad y valor. Sociología del trabajo, 74, 47-68.

Avvisati, F. (2015). Studens, Computers and Learning: Making the Connection. Paris: OECD Publishing. Retrieved from: http://dx.doi.org/10.1787/9789264239555-en

Barquín, J., et al. (2011). Los datos de las TIC en los centros, en SOLA, M. y MURILLO, J. F. (Coords.) Las TIC en la Educación. Realidad y expectativas. Informe anual 2011. Madrid: Fundación Telefónica.

Bunge, M. (2002). Crisis y reconstrucción de la filosofía. Barcelona: Gedisa.

Bustamante, E. (2011). Cultura digital: la "nueva" cultura clásica. Telos, 88, 1-5.

Castells, M. (2009). Comunicación y poder. Madrid: Alianza Editorial.

Cochran-Smith, M., et al. (2006). Estudio sobre la formación del profesorado en los Estados Unidos: descripción del informe del comité de la AERA sobre investigación y formación del profesorado. Revista de educación, 340, 87-116.

Coriat, B. (1991). El taller y el cronómetro. Madrid: Siglo XXI.

De Oliveira, J. M., et al. (2015). El panorama educativo de la era digital: prácticas comunicativas que (nos) impulsan hacia adelante. RUSC. Universities and Knowledge Society Journal, 12(2), 14-31. Retrieved from: http://dx.doi.org/10. 7238/rusc.v12i2.2440

Díaz Becerro, S. (2009). Introducción a las plataformas virtuales en la enseñanza. Temas para la educación. Revista Digital para profesionales de la enseñanza, 2, 1-7.

Durbin, P. (2007). There is an implicit social contract between professionals and the democratic societies in which they live. Ludus vitalis, 15(27), 195199.

García, A. (2015). Medios de interacción social y procesos de (de-re)formación de ciudadanías. Teoría de la Educación. Revista Interuniversitaria, 27(1), 85-101.

García, A., \& San Martín, A. (2014). Los procesos de innovación tecnológica en el ámbito educativo. In V. Martín García (Ed.), Blended Learning en Educación Superior (pp. 21-38). Madrid: Síntesis.

Hardt, M., \& Negri, A. (2002). Imperio. Barcelona: Paidós.

Hepp, K. P., et al. (2015). Formación de educadores: la tecnología al servicio del desarrollo de un perfil profesional innovador y reflexivo. RUSC. Universities and Knowledge Society Journal, 12(2), 30-43. http://dx.doi.org/10.7238/rusc.v12i2.2458

Hwang, G.-J., \& Tsai, C. (2011). Research trends in mobile and ubiquitous learning: a review of publications in selected journals from 2001 to 2010. British Journals of Educativonal Technology, 42(2), 65-70. Retrieved from: http://dx.doi.org/10.1111/j.1467-8535.2011.01183.x

Ibáñez-Martín, J. A. (2015). Sentido crítico, gran política y democracia mediática. Teoría de la Educación. Revista Interuniversitaria, 27(1), 53-67.

Innerarity, D. (2013). Un mundo de todos y de nadie. Barcelona: Paidós. 
Kovács, I. (2002). Cómo hacer visible el trabajo que el discurso dominante oculta. Sociología del Trabajo, 45, 25-51. Lankshear, C., Peters, M., \& Knobel, M. (2000). Information, Knowledge and Learning: Some Issues Facing Epistemology and Education a in a Digital Age. Journal of Philosophy of Education, 34(1), 17-39.

Luckin, R. (2010). Re-designing learning contexts: technology-rich, learner-centred ecologies. London: Routledge.

Míguez, P. (2008). Las transformaciones recientes de los procesos de trabajo: desde la automatización hasta la revolución informática. Trabajo y sociedad, X(11), 1-20. Retrieved from: http://www.unse.edu.ar/trabajoysociedad.

OECD. (2015a). Política educativa en perspectiva 2015. Hacer posibles las reformas. Madrid: Fundación Santillana-OCDE.

OECD. (2015b). Students. Computers and Learning: Making the Connection. OECD Publishing. Retrieved from: http://dx.doi.ogr/101787/9789264239555.en

Pedró, F. (2011). Tecnología y escuela: lo que funciona y por qué. Documento básico: XXVI Semana Monográfica de la Educación. Retrieved from: http://www.fundacionsantillana.com/.

Piscitelli, A. (2015). Humanidades digitales y nuevo normal educativo. Telos, 101, 1-10.

Quintanilla, M. A. (1998). Técnica y cultura. Teorema, XVII/3, 49-69.

Telefónica, F. (2014). Fabricación digital: Nuevos modelos de negocio y nuevas oportunidades para los emprendedores. Madrid: Ariel/Fundación Telefónica.

Tenti Fanfani, E. (2010). El oficio del maestro en el siglo XXI. En W.AA. La educación en el horizonte 2020. Madrid: Fundación Santillana. Retrieved from: http://www.fundacionsantillana.com.

\section{Submit your manuscript to a SpringerOpen ${ }^{\circ}$ journal and benefit from:}

- Convenient online submission

- Rigorous peer review

- Immediate publication on acceptance

- Open access: articles freely available online

High visibility within the field

- Retaining the copyright to your article 